\title{
Effect of ultrasound waves on hematological parameters, behavior and conduction system of heart in vitro in BALB/c strain mouse
}

\author{
Algimantas Bubulis ${ }^{1}$, Joris Vèžys ${ }^{2}$, Judita Žymantiené ${ }^{3}$, Rasa Želvyte் ${ }^{4}$, \\ Vaidas Oberauskas $^{5}$, Antanas Sederevičius ${ }^{6}$, Albina Aniuliene் $\dot{e}^{7}$ \\ ${ }^{1,2}$ Kaunas University of Technology, Institute of Mechatronics, Kaunas, Lithuania \\ ${ }^{3,4,5,6}$ Lithuanian University of Health Sciences, Veterinary Academy, Department of Anatomy and \\ Physiology, Kaunas, Lithuania \\ ${ }^{7}$ Lithuanian University of Health Sciences, Veterinary Academy, Department of Veterinary Pathobiology, \\ Kaunas, Lithuania \\ ${ }^{1}$ Corresponding author \\ E-mail: 19algimantas.bubulis@ktu.lt, ${ }^{2}$ joris.vezys@ktu.edu, ${ }^{3}$ judita.zymantiene@lsmuni.lt, \\ ${ }^{4}$ rasa.zelvyte@lsmuni.lt, ${ }^{5}$ vaidas.oberauskas@lsmuni.lt, ${ }^{6}$ antanas.sederevicius@lsmuni.lt, \\ ${ }^{7}$ albina.aniuliene@lsmuni.lt
}

Received 2 September 2019; accepted 8 September 2019 DOI https://doi.org/10.21595/vp.2019.20999

Check for updates

Copyright $(2019$ Algimantas Bubulis, et al. This is an open access article distributed under the Creative Commons Attribution License, which permits unrestricted use, distribution, and reproduction in any medium, provided the original work is properly cited.

\begin{abstract}
In this study research was carried out on 5 male adult BALB/c mouse with a weight of $18 \pm 5 \mathrm{~g}$. The temperature was at $22 \pm 2{ }^{\circ} \mathrm{C}$ and animals were kept under the condition of $12 \mathrm{~h}$ of light and $12 \mathrm{~h}$ of darkness (light on at 08:00 am) and free access to water and standard diet. All 5 mice were affected by three different harmonic oscillations one time and after 24 hours 4 of them were affected by the same oscillations (Fig. 1) and one was placed separately for control. At the end of the experiment, after euthanasia using $\mathrm{CO} 2$ chamber blood samples were collected by cardiac puncture. We noticed that ultrasound waves $20 \mathrm{MHz}$ changed mice red blood cells structure and we found pathological forms of erythrocytes. Analysing morphological structure of erythrocytes were determined 46 abnormal red blood structure forms and atypical cells (30 codocytes, 8 stomatocytes and 8 acantocytes). Moreover, we determined that changed some normal behavior characteristics and increased grooming process.
\end{abstract}

Keywords: ultrasound waves, hematological parameters, heart in vitro, strain mouse.

\section{Introduction}

The use of high-frequency oscillations in the study of vascular pathology has been described in scientific papers $[1,2]$. Ultrasound imaging can replace more invasive techniques that cause pain and distress [3]. Ultrasound is acoustic (sound) energy in the form of waves having a frequency above 20 thousand cycles per second $(20.000 \mathrm{~Hz})$. Ultrasound is used in medicine to view internal organs of the body, electronic, navigational, industrial, and security applications. Moreover, exposure of ultra wave sounds for a long period of time may influence heart and/or liver function or structure and/or other tissues $[5,6]$.

The ventricular conduction system represents the electrical wiring responsible for the coordination of cardiac contraction. Defects in the circuit produce a delay or conduction block and induce cardiac arrhythmia. defects in the ventricular conduction system are a major cause of arrhythmias and deciphering the molecular pathways responsible for conduction system morphogenesis and the differentiation of conductive myocytes furthers our understanding of the mechanisms underlying heart disease [3].

The main aim of this study was to determine different effect of ultrasound waves on hematological parameters, behavior and conduction system of heart in vitro in BALB/c strain mouse. 


\section{Materials and methods}

Animals and protocol of study. In this study research was carried out on 5 male adult BALB/c mouse with a weight of $18 \pm 5 \mathrm{~g}$. The temperature was at $22 \pm 2{ }^{\circ} \mathrm{C}$ and animals were kept under the condition of $12 \mathrm{~h}$ of light and $12 \mathrm{~h}$ of darkness (light on at 08:00 am) and free access to water and standard diet. All 5 mice were affected by three different harmonic oscillations one time and after 24 hours 4 of them were affected by the same oscillations (Fig. 1) and one was placed separately for control. At the end of the experiment, after euthanasia using $\mathrm{CO}_{2}$ chamber blood samples were collected by cardiac puncture. During dissection the hearts were removed from BALB/c mice body and put in to $0.85 \% \mathrm{NaCl}$ solution. Heartbeat rate were calculated via $15 \mathrm{~s}$ and minute using chronometer. Red blood cells morphology were analysed from the prepared slides which were stained with reagent. Hematocolor and characterized using a light microscope. The count of red blood cells (RBC), and haemoglobin content $(\mathrm{Hb})$ were analyzed by the QBC Autoread Plus system (QBC Diagnostics Inc., USA). Diagnostics Inc., USA). Oxygen consumption (DKT) was calculated according to the haemoglobin concentration coefficient in blood. Measurements of mice activity and behavioral characteristics were observed using [7, 8] method after 24 hours using ultrasounds waves.

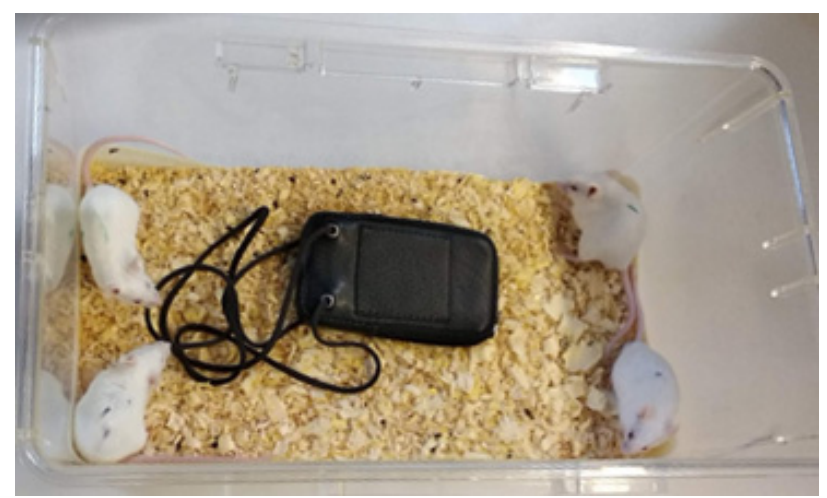

Fig. 1. Mice were affected by harmonic oscillations

Experiment with animals was in compliance with the rules of the national Animal Ethics Committee and the protocols were designed according to European Parliament Directive 2010/63 EU.

\section{Results}

Analysing morphological structure of erythrocytes were determined 46 abnomal red blood structure forms and atipical cells (30 codocytes, 8 stomatocytes and 8 acantocytes).

Table 1. Influence of different ultrasound waves on hematological parameters of mouse

\begin{tabular}{|c|c|c|c|c|c|}
\hline Parameter & $\begin{array}{c}\text { No 1 } \\
\text { (ultrasound 2 } \\
\text { times) }\end{array}$ & $\begin{array}{c}\text { No 2 } \\
\text { (ultrasound } \\
\text { 2 times) }\end{array}$ & $\begin{array}{c}\text { No 3 ultrasound } \\
\text { before 24 h. 1 time } \\
\text { (control) }\end{array}$ & $\begin{array}{c}\text { No 4 } \\
\text { (ultrasound 2 } \\
\text { times) }\end{array}$ & $\begin{array}{c}\text { No 5 } \\
\text { (ultrasound 2 } \\
\text { times) }\end{array}$ \\
\hline $\begin{array}{c}\text { Red blood cells } \\
\mathrm{X} \times 10^{12} / 1\end{array}$ & 9.3 & 8.9 & 9.7 & 11.7 & 14.8 \\
\hline Codocytes U, \% & $7(23.33)$ & $4(13.33)$ & $4(13.33)$ & $6(20.00)$ & $9(30.00)$ \\
\hline Stomatocytes U, \% & 0 & $3(37.5)$ & $2(25.00)$ & $1(12.50)$ & $2(25.00)$ \\
\hline Acantocytes U, \% & 0 & $1(12.50)$ & $5(62.50)$ & $2(25.00)$ & - \\
\hline Hb (haemoglobin) g/1 & 111 & 102 & 120 & 112 & 112 \\
\hline $\begin{array}{c}\text { DKT, O } \text { /ml (Oxygen } \\
\text { consumption in blood) }\end{array}$ & 148.74 & 136.68 & 160.80 & 150.08 & 150.08 \\
\hline
\end{tabular}


EFFECT OF ULTRASOUND WAVES ON HEMATOLOGICAL PARAMETERS, BEHAVIOR AND CONDUCTION SYSTEM OF HEART IN VITRO IN BALB/C STRAIN MOUSE. AlgIMANTAS BubULIS, JORIS VĖŽYS, JUDITA ŽYMANTIENĖ, RASA ŽELVYTĖ, VAIDAS OBERAUSKAS, ET AL.

Table 2. Influence of ultrasound waves on behavior of mouse

\begin{tabular}{|c|c|c|c|c|c|c|}
\hline & WA & CL & BGRO & HL & FGR & SL \\
\hline No 1 (before experiment) & + & + & - & - & - & - \\
\hline No 2 & + & + & - & - & - & - \\
\hline No 3 & + & + & + & - & - & - \\
\hline No 4 & + & - & + & - & - & - \\
\hline No 5 & + & - & - & - & - & - \\
\hline No 1 after 3 min using ultrasound & + & - & - & - & - & - \\
\hline No 2 & + & - & - & - & - & - \\
\hline No 3 & + & + & - & - & - & - \\
\hline No 4 & + & - & - & - & - & - \\
\hline No 5 & - & - & + & - & - & - \\
\hline No 2 & + & + & + & - & - & - \\
\hline No 3 & + & - & - & + & - & - \\
\hline No 4 & + & + & + & + & - & - \\
\hline No 5 & - & - & + & + & + & - \\
\hline No 1 after 24 h using ultrasound & - & - & - & + & + & + \\
\hline
\end{tabular}

Walking - WA; Climbing of the top grate of cage - CL; Grooming body - BGRO; Grooming hind leg HL; Grooming face - FGR; Sleeping - SL

Table 3. Influence of different ultrasound waves on heart conductive system of mouse in vitro

\begin{tabular}{|c|c|c|c|c|c|}
\hline Heart beat rate & $\begin{array}{c}\text { No } 1 \\
\text { (via 15 s and } \\
1 \mathrm{~min} \text { ) }\end{array}$ & $\begin{array}{c}\text { No } 2 \\
\text { (via 15 s } \\
\text { and 1 min) }\end{array}$ & $\begin{array}{c}\text { No 3 } \\
\text { (via 15 s and } \\
1 \mathrm{~min} \text { ) }\end{array}$ & $\begin{array}{c}\text { No } 4 \\
\text { (via 15 s } \\
\text { and 1 min) }\end{array}$ & $\begin{array}{c}\text { No } 5 \\
\text { (via 15 s and } \\
1 \mathrm{~min} \text { ) }\end{array}$ \\
\hline $\begin{array}{c}\text { Before using ultrasound } \\
\text { via 15 s, 1 min }\end{array}$ & $10 / 40$ & $7 / 28$ & $15 / 60$ & $5 / 20$ & $12 / 48$ \\
\hline After 15 s, 1 min & $9 / 36$ & $7 / 28$ & $13 / 52$ & $4 / 16$ & $16 / 64$ \\
\hline After 30 s, 1 min & $8 / 32$ & $7 / 80$ & $12 / 48$ & $4 / 16$ & $12 / 48$ \\
\hline After 45 s, 1 min & $3 / 12$ & $5 / 20$ & $12 / 48$ & $5 / 20$ & $10 / 40$ \\
\hline After 1 min & $8 / 32$ & $5 / 20$ & $1 / 4$ & $4 / 16$ & $8 / 32$ \\
\hline After 1 min 15 s & $1 / 4$ & $4 / 16$ & $0 / 0$ & $3 / 12$ & $8 / 32$ \\
\hline After 1 min 30 s & 0 & 0 & 0 & 0 & 0 \\
\hline
\end{tabular}

No 1. Changes of activity of heart conductive system was $26 \pm 5.91$ (95\% CI:10.8-41.2)

No 2. Changes of activity of heart conductive system was $23.33 \pm 2.17$ (95 \% CI:17.75-28.92).

No 3. (control) Changes of activity heart conductive system was $35.33 \pm 10.70$ (95\% CI:7.8-62.87).

No 4. Changes of activity of heart conductive system was $16.67 \pm 1.22$ (95\% CI:13.5-19.83).

No 5. Changes of activity of heart conductive system was 44.00 \pm 1.22 (95\% CI:32.26-56.74).

\section{Conclusions}

The mouse is the animal of choice for the study of molecular mechanisms involved in the regulation of cardiovascular morphogenesis and function [4].

We noticed that ultrasound waves $20 \mathrm{MHz}$ changed mice red blood cells structure and we found pathological forms of erythrocytes. Analysing morphological structure of erythrocytes were determined 46 abnomal red blood structure forms and atypical cells ( 30 codocytes, 8 stomatocytes and 8 acantocytes). Moreover, we determined that changed some normal behavior characteristics and increased grooming process.

\section{References}

[1] Bubulis Algimantas, Garalienė Vida, Jūrėnas Vytautas, Navickas Jonas, Giedraitis Saulius Effect of low intensity cavitation on the isolated human thoracic artery in vitro. Ultrasound in Medicine and Biology, Vol. 43, Issue 5, 2017, p. 1040-1047. 
[2] Bubulis Algimantas, Venslauskas Mantas, Navickas Jonas, Abramavičius Silvijus, Stankevičius Edgaras Experimental investigation of the determination for the safe operating regime of ultrasound tube-shaped waveguide wire for internal blood vessel debulking. Technology and Health Care, Vol. 26, Issue 2, 2018, p. 625-634.

[3] Miquerol Lucile, Beyer Sabrina, Kelly Robert G. Establishment of the mouse ventricular conduction system. Cardiovascular Research, Vol. 91, Issue 2, 2011, p. 232-242.

[4] Wessels A., Phelps A., Trusk T. C., Davis D. L., Edwards A. V., Burch J. B., Juraszek A. L. Mouse models for cardiac conduction system development. Novartis Foundation Symposia, Vol. 250, 2003, p. 44-59.

[5] Viswanathan S., Burch J. B. E., Fishman G. I., Moskowitz I. P., Benson D. W. Characterization of sinoatrial node in four conduction system marker mice. Journal of Molecular and Cellular Cardiology, Vol. 42, Issue 5, 2007, p. 946-953.

[6] Kheyrvari J., Ahmadi R., Moradi Sh The effects of ultra sound waves on serum levels of AST and ALTin male rats. 5th International Conference on Biological, Chemical and Environmental Sciences, 2016.

[7] Cootney Robert W. Ultrasound imaging: principles and applications in rodent research. ILAR Journal, Vol. 42, 2001, p. 233-247.

[8] Arbeille P., Eder V., Casset D., Quillet L., Hudelo C., Herault S.. Real-time 3-D ultrasound acquisition and display for cardiac volume and ejection fraction evaluation. Ultrasound in Medicine and Biology, Vol. 26, 2000, p. 210-208. 